\title{
PENGENALAN GREEN BEHAVIOR MELALUI ECOLITERACY PADA ANAK USIA SEKOLAH DASAR DI DESA ADAT KAMPUNG NAGA KABUPATEN TASIKMALAYA
}

\author{
Gia Nika Wanti, Rayi Siti Fitriani, Yudi Bachtiar
}

STKIP Purwakarta

\section{Kata Kunci :}

Green Behaviour, Ecoliteracy \& Anak Sekolah Dasar
Email penulis:

gyanikawanti@upi.edu

\begin{abstract}
This study aims at finding out whether elementary school-age children in the traditional village of Naga village already have green behavior and want to know how the way elementary schoolage children in Naga village traditional village preserve the surrounding environment. After conducting research, the team carried out the development stage, which was to carry out the steps to recognize green behavior through ecoliteracy for elementary school children in the Naga village traditional village and then find out how effective the introduction of green behavior through ecoliteracy in elementary school-age children in the Naga village. The results of this study will be used as an output plan for the research team to develop science and technology in the form of child-friendly pop up books related to the introduction of green behavior through ecoliteracy
\end{abstract}

\begin{abstract}
ABSTRAK
Penelitian ini bertujuan untuk mengetahui apakah anak usia sekolah dasar di desa adat kampung Naga sudah memiliki green behavior serta ingin mengetahui bagaimanakah cara anak usia sekolah dasar di desa adat kampung Naga menjaga kelestarian alam sekitar. Setelah melakukan research, tim melakukan tahap development yaitu melakukan langkah-langkah pengenalan green behavior melalui ecoliteracy untuk anak usia sekolah dasar di desa adat kampung Naga lalu selanjutnya mencari tahu seberapa efektifkah pengenalan green behavior melalui ecoliteracy pada anak usia sekolah dasar di desa adat kampung Naga. Hasil dari penelitian ini akan dijadikan sebagai rencana luaran tim peneliti guna mengembangkan IPTEK (Ilmu Pengetahuan dan Teknologi) berupa pop up book ramah anak berkaitan dengan pengenalan green behavior melalui ecoliteracy
\end{abstract}

\section{PENDAHULUAN}

Kampung Naga terletak di kabupaten Tasikmalaya Jawa Barat di mana masyarakat adat setempat masih menjaga adat istiadat dan menjungjung tinggi local wisdom. Terpeliharanya adat istiadat masyarakat kampung Naga berasal dari keyakinan yang dipegang oleh setiap masyarakat melalui tradisi budaya turun temurun. Keyakinan hidup yang harus tetap mereka pegang kukuh berkaitan dengan perbuatan yang berhubungan dengan sebab akibat yang 
mereka sebut sebagai budaya pamali. Keyakinan hidup mereka tersebut diperlihatkan dengan keharmonisan yang mereka ciptakan baik sebagai makhluk Tuhan, makhluk sosial, dan makhluk yang mendiami alam semesta dalam melakoni kehidupan.

Seperti yang digambarkan oleh Her (2006) masyarakat kampung Naga secara adat membagi wilayahnya menjadi tiga wilayah. Wilayah pertama, adalah wilayah suci yaitu hutan keramat yang di sebut sebagai hutan larangan. Wilayah kedua, adalah wilayah bersih yaitu daerah pemukiman penduduk setempat. Wilayah ketiga, adalah wilayah kotor yaitu tempat yang meliputi tempat untuk melakukan aktivitas MCK (Mandi, Cuci, dan Kakus). Budaya turun temurun tersebut berkaitan dengan keyakinan hidup masyarakat adat setempat sebagai hasil sebab akibat perbuatan dalam menjaga tiga wilayah. Perbuatan tersebut terlihat dari pola kehidupan masyarakat adat setempat menjaga ekosistem alam di kampung Naga.

Hasil studi lapangan yang sebelumnya dilakukan oleh tim peneliti ke kampung Naga menemukan bahwa masyarakat adat menaati peraturan adat yang diberikan oleh kuncen yang diperoleh dari budaya turun temurun yang diwariskan dari zaman nenek moyang sehingga masyarakat adat tunduk pada peraturan adat tersebut salah satunya tunduk kepada peraturaan tentang tidak boleh merusak lingkungan alam sekitar dengan tidak boleh masuknya mereka ke dalam hutan yang mereka sebut sebagai hutan larangan. Hal tersebut sejalan dengan yang digambarkan oleh Widianti (2014) bahwa masyarakat kampung Naga sangat menjaga lingkungan sekitarnya dengan cara menanam tanaman untuk bumbu dapur dan untuk keperluan ritual. Menanam padi atau memanen padi sebagai bentuk penghormatan terhadap alam. Selain itu, masyarakat Kampung Naga sangat menjaga hutan yang ada di sekitarnya karena hukum yang diberikan leluhurnya untuk tidak mengganggu hutan di sekitar kampung.

Budaya menjaga lingkungan alam sudah ditanamkan sejak dini dari orang tua kepada anakanak mereka berlandasakan budaya pamali yang diwariskan secara turun temurun oleh para leluhur. Subroto dan Setiawan (2014) menjelaskan bahwa pamali adalah pantangan atau hal tabu yang tidak boleh dilakukan. Pamali sebenarnya dapat dilogikan secara keilmuan sebagai suatu proses sebab akibat dalam berperilaku. Proses manusia memiliki pemahaman adanya sebab akibat berhubungan dengan proses kognitif manusia tersebut. Piaget (1995) menjelaskan bahwa individu mempunyai pemahan konsep sebab akibat dimulai dari tahapan kognitif operasional konkrit. Tahapan kognitif operasional konkrit tersebut ada dalam rentang usia 7-12 tahun di mana rentang usia ini masuk ke dalam kategori usia anak sekolah dasar. Pada tahap ini individu sudah dapat mengetahui fenomena yang dapat mereka kaji dengan berpikir secara operasional. Tujuan dari tidak boleh menjamah hutan larangan tersebut bukan sekedar larangan semata yang tidak mempunyai alasan tetapi larangan tersebut bertujuan agar masyarakat adat setempat tidak melakukan perilaku merusak alam sehingga masyrakat adat setempat dapat menjaga lingkungan alam sekitar.

Asumsi dasar yang diasumsikan oleh tim peneliti memandang tujuan masyarakat kampung adat tidak boleh menjamah hutan laraangan tersebut sejalan dengan konsep ecoliteracy. Ecoliteracy adalah cara untuk menciptakan pemahaman masyarakat akan pentingnya 
kesadaran ekologis global, sehingga terciptanya keseimbangan antara sumber daya alam dengan kebutuhan masyarakat. Sejalan dengan penjelasan dari Capra (2011) ecoliteracy adalah cara berpikir tentang kesadaran lingkungan secara global yang berguna untuk menciptakan keseimbangan antara kebutuhan masyarakat dan potensi alam yang tersedia dengan mempertimbangkan konsekuensi dari tindakan manusia dalam memanfaatkan alam. Maka dari itu Ecoliteracy dapat dipahami sebagai perilaku membangun kesadaran untuk melestarikan ekosistem ke dalam pikiran masyarakat. Ecoliteracy akan menghasilkan suatu perilaku yang disebut dengan perilaku melestarikan lingkungan atau disebut juga sebagai green behavior.

Dari hasil yang dilatarbelakangi oleh pemaparan di atas dirasa perlu untuk dilakukan penelitian tentang pengenalan green behavior melalui ecoliteracy pada anak usia sekolah dasar di desa adat kampung Naga Kabupaten Tasikmalaya.

\subsection{Tujuan Penelitian}

1. Ingin mengetahui apakah anak usia sekolah dasar di desa adat kampung Naga sudah memiliki green behavior.

2. Ingin mengetahui bagaimanakah cara anak usia sekolah dasar di desa adat kampung Naga menjaga kelestarian alam sekitar.

3. Melakukan langkah-langkah pengenalan green behavior melalui ecoliteracy untuk anak usia sekolah dasar di desa adat kampung Naga.

4. Ingin mengetahui seberapa efektifkah pengenalan green behavior melalui ecoliteracy pada untuk anak usia sekolah dasar di desa adat kampung Naga.

\subsection{Rumusan Masalah}

1. Apakah anak usia sekolah dasar di desa adat kampung Naga sudah memiliki green behavior?

2. Bagaimanakah cara anak usia sekolah dasar di desa adat kampung Naga menjaga kelestarian alam sekitar?

3. Bagaimanakah langkah-langkah pengenalan green behavior melalui ecoliteracy untuk anak usia sekolah dasar di desa adat kampung Naga?

4. Seberapa efektivkah pengenalan green behavior melalui ecoliteracy pada untuk anak usia sekolah dasar di desa adat kampung Naga?

\section{METODE PENELITIAN}

Desain penelitian yang digunakan adalah desain penelitian $\mathrm{R} \& \mathrm{D}$ (Research and Development). Menurut Sugiyono (2009) desain penelitian R \& D adalah desain penelitian yang digunakan untuk menghasilkan produk tertentu dan menguji keefektifan produk tersebut. Kegiatan penelitian ini dimulai dengan terlebih dahulu melakukan research lalu diteruskan dengan melakukan development. Kegiatan research dilakukan untuk mendapatkan informasi tentang kebutuhan pengguna (needs assessment) sedangkan kegiatan development dilakukan untuk menghasilkan produk atau perangkat.

Adapun langkah-langkah penelitian R\&D yang akan dilakukan sebagai berikut : 

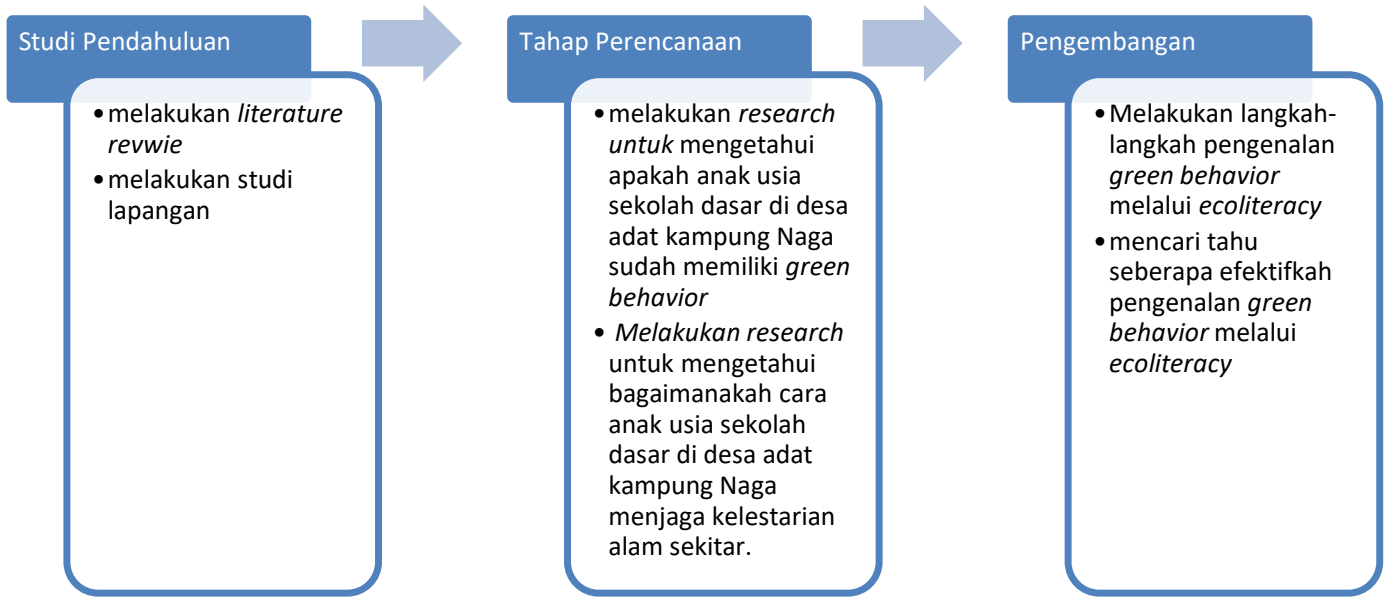

Penelitian ini akan dilaksanakan selama 1 tahun. Tempat dilaksanakan penelitian yaitu di Desa adat kampung Naga kabupaten Tasikmalaya. Objek pada penelitian ini adalah anakanak usia sekolah dasar di desa adat kampung Naga kabupaten Tasikmalaya. Instrumen yang digunakan dalam penelitian ini adalah lembar observasi, studi dokumentasi dan rubrik uji produk.

\section{HASIL DAN PEMBAHASAN}

Hasil dari penelitian ini adalah produk yang dikembangkan dari research tentang pengenalan green behaviour melalui ecoliteracy berupa produk pop up book. Langkah-langkah penelitian yang dilakukan merujuk pada Borg \& Gall (1983):

1) Potensi dan Masalah

Potensi dan masalah dari penelitian ini berawal dari isu-isu tentang lingkungan hidup dan berkembangnya penelitian yang berkaitan dengan pendidikan lingkungan hidup. Kampung Naga adalah salah satu tempat cagar budaya dan cagar lingkungan di mana kampung adat tersebut masih memegang nilai-nilai budaya setempat yang berkaitan dengan menjaga lingkungan hidup secara turun temurun.

2) Mengumpulkan Informasi

Pada tahapan selanjutnya peneliti melakukan pengumpulan informasi. Pengumpulan informasi dilakukan melalui studi literatur dan observasi sehingga didapatkan perencanaan produk yang diharapkan sebagai solusi untuk mengatasi masalah yang berkaitan dengan isu lingkungan hidup di kampung Naga.

3) Desain Produk. Produk beupa buku pop up book bertemakan lingkungan hidup dengan latar tempat kampung Naga. Pembuatan desain dirancang oleh para tim peneliti dibantu oleh para pakar desian grafis dan desain buku anak. Pembuatan produk buku pop up book ini bertujuan agara anak-anak dapat mempunyai kesadaran untuk mencintai lingkungan hidup di sekitar mereka melalui cerita yang dirancang sesuai dengan perkembangan bahasa, perkembangan kognitif, perkembangan sosialemosional, perkembangan moral dan perkembangan spiritual.

4) Validasi Desain

Validasi desain dilakukan untuk menilai produk dan mengetahui kekuatan serta kelemahan produk melalui FGD dari pakar desian grafis dan para dosen pendidikan dasar.

5) Perbaikan Desain 
Kelamahan dari produk pop up book terdapat pada bahan kertas yang awal desainnya memakai kertas jenis karton. Setelah diperbaiki tim memakai standar pop up book sebagai berikut:

\begin{tabular}{|l|l|}
\hline Ukuran: & ukuran: 82mmW x 100mmL x 25mmD \\
\hline Sejauh: & 12 menyebar + penutup + Pop ups \\
\hline Kertas & teks/Pop up: 4c + Glossy laminasi + Foil stamping x 0c; 300G C1S \\
$\&$ & Papan abu-abu \\
Bahan: & penutup: 4c + Foil stamping x 0c; 128G artPaper mengkilap \\
\hline
\end{tabular}

6) Uji coba produk

Uji coba produk dilakukan kepada anak usia dini dan anak sekolah dasar. Mereka melakukan review pada produk pop up book mulai dari ukuran buku, warna buku, dan tokoh cerita dalam pop up book.

7) Revisi produk ini di lihat dari pengujian pop up book. Setelah tahap perbaikan desain pop up book dilakukan perbaikan dan pencetakan sample produk kembali yang akan dilanjutkan dengan uji coba pemakaian.

8) Uji coba pemakaian

Setelah revisi produk pop up book selesai maka produk siap di produksi dalam bentuk produk yang sudah sesuai setelah lolos revisi produk.

9) Revisi produk

Pada tahapan revisi produk ini tidak dilakukan karena produk sudah diuji coba dan lolos revisi produk sebelumnya.

10) Pembuatan produk masal

Tahapan akhir adalah pembuatan produk masal pop up book. Namun, sampai saat ini pembuatan produk masal masih dalam tahap proses pencetakan.

\section{KESIMPULAN}

Penelitian ini menghasilkan produk dari hasil research yang dilakukan sebelumnya tentang pengenalan green behaviour melalui ecoliteracy pada anak sekolah dasar di kampung Naga Tasikmalaya. Produk dari hasil pengembangan research tersebut berupa pop up book yang bertemakan cinta lingkungan. Implikasi dari penelitian ini masih dilakukan proses pencetakan buku dan keterbatasan waktu terlebih pada proses pengembangan hasil produk.

\section{REFERENSI}

Borg. W.R. dan Gall, M.D. (1983). Educational research: an introduction. New York: Longman.

Her, Suganda. (2006). Kampung naga mempertahankan tradisi. Bandung: PT Kiblat. Capra, F. (2002). Jaring-jaring kehidupan. Yogyakarta: Fajar Pustaka Baru.

Piaget, J. (1995). Sociological studies. New York/London: Routledge.

Subroto, Amanda, Nabila,.\& Setiawan, Pindi. (tt). Perancangan Buku Ilustrasi Mengenai Pamali Sunda Seputar Kehamilan. Jurnal Tingkat Sarjana Bidang Seni Rupa dan Desain. Bandung: ITB. (1), p. 1-6. 
Sugiono. (2008). Metode penelitian pendidikan: pendekatan kuantitatif, kualitatif dan $R \& D$. Bandung: Alfabeta.

Widianti, Tresna, Novita. (2014). Studi potensi kampung naga sebagai sebuah ecovillage. Skripsi. Bogor: IPB. 